\title{
Islet Amyloid Polypeptide Measurement
}

National Cancer Institute

\section{Source}

National Cancer Institute. Islet Amyloid Polypeptide Measurement. NCI Thesaurus. Code C127622.

The determination of the amount of islet amyloid polypeptide present in a sample. 